\title{
Gagrak Blitaran: Proses Belajar Kebudayaan di Paguyuban Turonggo Budoyo Mugirejo
}

\author{
Gagrak Blitaran: Cultural Learning Process in Paguyuban Turonggo Budoyo \\ Mugirejo
}

David Bagus Yulinanda*, Program Studi Etnomusikologi, Fakultas Ilmu Budaya, Universitas Mulawarman. Email: davidbagus70@gmail.com

Yofi Irvan Vivian, Program Studi Etnomusikologi, Fakultas Ilmu Budaya, Universitas Mulawarman. Email: yofiyochi@yahoo.com

Aris Setyoko, Program Studi Etnomusikologi, Fakultas Ilmu Budaya, Universitas Mulawarman. Email: aris.setyoko@fib.unmul.ac.id

\author{
Received: \\ 3 Maret 2021 \\ Accepted: \\ 30 Maret 2021 \\ Published: \\ 3 April 2021
}

\section{Keywords:}

kuda lumping, gagrak blitaran, the study of culture.

\section{Kata kunci:}

kuda lumping, gagrak blitaran, belajar kebudayaan.

\begin{abstract}
:
Turonggo Budoyo Mugirejo is a Kuda Lumping group Gagrak Blitaran in the city of Samarinda through the transmigration process. Gagrak Blitaran, on its own, was the identity of this group. The process of learning culture alone played a crucial role in preserving Kuda Lumping Gagrak Blitaran in Samarinda. This study aims to explain the characteristics of Gagrak Blitaran's music; describe the process of self-study at the Turonggo Budoyo Mugirejo. The study employs qualitative methodologies by applying three phases, some of which define the location of research, data collection techniques, and analysis. Determination of the location aims to focus on the object of research. Data-collection techniques include library studies, informers, interviews, and documentation. The last one is the analysis technique by utilising field data. The study results in accord with the background of the problem and the purpose of the study. Gagrak Blitaran's music characteristic have been achieved through the four rhythms of sampak, gangsaran, dua-satu (pegon and dangdutan), and satu-satu. The instruments on which these rhythms are based are the kenong, kempul, gong suwukan, and gong ageng. The process of learning its own culture includes internalisation, socialisation and enculturation. The three processes allow each member of the company to have a deeper understanding of Kuda Lumping. It involves a dance technique, beating the Gamelan according to the characteristic of Kuda Lumping Gagrak Blitaran.
\end{abstract}

\begin{abstract}
Abstrak:
Turonggo Budoyo Mugirejo merupakan paguyuban Kuda Lumping Gagrak Blitaran di Kota Samarinda melalui proses transmigrasi. Gagrak Blitaran sendiri merupakan identitas dari paguyuban ini. Proses belajar kebudayaan sendiri berperan penting dalam keberlanjutan kesenian Kuda Lumping Gagrak Blitaran di Kota Samarinda. Penelitian ini bertujuan: menjelaskan bagaimana karakteristik musik Gagrak Blitaran; Mendeskripsikan proses belajar kebudayaan sendiri di Paguyuban Turonggo Budoyo Mugirejo. Penelitian ini mengunakan metodologi kualitatif dengan menerapkan tiga tahapan, diantaranya menentukan lokasi penelitian, teknik pengumpulan data, dan analisis. Penentuan lokasi bertujuan untuk memfokuskan objek penelitian. Teknik pengumpulan data meliputi studi pustaka, penentuan informan, wawancara, dan dokumentasi. Terakhir adalah teknik analisis dengan memanfaatkan data-data lapangan. Penelitian ini mendapatkan hasil sesuai dengan latar belakang masalah dan tujuan penelitian. Karakteristik musik Gagrak Blitaran diwujudkan melalui empat
\end{abstract}


irama, yaitu sampak, gangsaran, 2-1 (pegon dan dangdutan), serta 1-1. Alat musik yang menjadi dasar keempat irama ini adalah kenong, kempul, gong suwukan, dan gong ageng. Proses belajar kebudayan sendiri meliputi internalisasi, sosialisasi, dan enkulturasi. Ketiga proses tersebut membuat setiap anggota paguyuban memiliki pemahaman lebih mengenai kesenian Kuda Lumping. Pemahaman tersebut meliputi teknik menari, menabuh gamelan sesuai dengan ciri khas Kuda Lumping Gagrak Blitaran.

\section{Citation:}

Yulinanda, D. B., Vivian, Y. I., \& Setyoko, A. (2021). Gagrak Blitaran: Proses Belajar Kebudayaan di Paguyuban Turonggo Budoyo Mugirejo. Jurnal Mebang: Kajian Budaya Musik dan Pendidikan Musik, 1(1), 1-13. http://jurnal.fibunmul.id/index.php/mebang/article/view/1

\section{Pendahuluan}

Transmigrasi mengkonstruksi manusia sekaligus kebudayaan yang dimilikinya untuk berpindah tempat. Kebudayaan yang biasanya dibawa oleh penduduk transmigran salah satunya adalah kesenian. Kesenian menjadi ruang bernostalgia akan masa lalu yang dimiliki manusia secara individu maupun kolektif, salah satunya adalah Paguyuban Turonggo Budoyo Mugirejo. Kesenian yang dibawa oleh paguyuban ini adalah tari kuda lumping. Tari kuda kumping atau jaranan merupakan drama tari rakyat yang lahir dan tumbuh di masyarakat suku Jawa (Hanifati, 2016, p. 164). Perlu adanya proses belajar kebudayaan (salah satunya kesenian) untuk menghadirkan ruang bernostalgia. Koentjaraningrat menjelaskan bahwa proses belajar kebudayaan sendiri itu terdiri atas internalisasi, sosialisasi, dan enkulturasi (Koentjaraningrat, 2009, p. 181).

Menurut Agung Nugroho selaku narasumber, Paguyuban Turonggo Budoyo Mugirejo merupakan kelompok kesenian kuda lumping Gagrak Blitaran ${ }^{1}$. Tari Kuda Lumping Gagrak Blitaran dapat dilihat dari beberapa aspek, salah satunya karakteristik irama dasar musiknya dan tariannya. Irama dasar yang digunakan untuk mengiringi setiap tarian ialah sampak, gangsaran, 2-1, dan 1-1. Tarian yang biasa dibawakan oleh Paguyuban Turonggo Budoyo Mugirejo dalam penampilannya, adalah Tari Kesatria Tamtama, Celeng, Singo Barong, Jaran Tril, dan Rampokan.

Budaya merupakan suatu kesatuan utuh yang menyeluruh, memiliki beragam aspek dan perwujudan, serta dipahami melalui suatu proses belajar (Suharyanto, 2015, p. 164). Hal ini yang menyebabkan Paguyuban Turonggo Budoyo Mugirejo mengadakan pelatihan mengenai Gagrak Blitaran dari aspek musik maupun tari. Kegiatan ini berguna untuk menjaga kesenian tradisi dan sebagai pengingat akan akar budaya yang seharusnya mereka miliki.

Pada penelitian ini, penulis melihat Paguyuban Turonggo Budoyo Mugirejo menguatkan Gagrak Blitaran sebagai identitas pada kesenian Kuda Lumping. Fokus penelitian yang pertama adalah untuk membedah karakteristik musik Gagrak Blitaran di Paguyuban Turonggo Budoyo Mugirejo. Kedua, untuk melihat mengenai proses belajar kebudayaan yang dilakukan oleh Paguyuban Turonggo Budoyo Mugirejo mengenai Gagrak Blitaran.

Fokus penelitian ini adalah Kesenian Kuda Lumping di Paguyuban Turonggo Budoyo Mugirejo Kota Samarinda. Khusunya mengenai karakteristik musik Gagrak Blitaran dan proses belajar kebudayaan sendiri di Paguyuban Turonggo Budoyo Mugirejo. Penulis

\footnotetext{
1 Gagrak Blitaran merupakan pola, gaya, mahzab, atau corak dari daerah Blitar, dalam hal ini adalah bentuk kesenian kuda lumping.
} 
mendeskripsikan penelitiannya dengan mengkorelasikan beberapa teori yang berhubungan dengan objek permasalahan. Pertama, berkaitan mengenai karakteristik musik Kuda Lumping Gagrak Blitaran di Paguyuban Turonggo Budoyo Mugirejo. Berdasarkan data yang diperoleh di lapangan, terdapat empat irama yang mencirikan musik Gagrak Blitaran. Keempat irama tersebut adalah sampak, gangsaran, 2-1, dan 1-1. Penulis melihat bahwa keempat irama tersebut memiliki ciri khas dan fungsinya masing-masing dalam mengiringi tarian Kuda Lumping. Hal inilah yang melatar belakangi penulis untuk membedah bagaimana karakteristik musik Gagrak Blitaran melalui keempat irama tersebut.

Kesenian Kuda Lumping merupakan objek dari penelitian ini, proses analisis dan transkrip musik akan mengikuti aturan musik Jawa, baik itu dalam penggunaan istilah maupun notasi. Hasil dokumentasi dalam bentuk video dan audio akan dianalisis dan ditranskripkan menggunakan notasi Kepatihan. Teori musik barat penulis gunakan untuk menjelaskan tentang motif, dinamika, unsur nada seperti pitch, duration, intensity, dan timbre pada setiap irama. Menurut Nettl (2012, p. 263), cara terbaik untuk memahami musik adalah dengan mengetahui konteks budayanya.

Kedua, berkaitan dengan konteks budaya yang terdapat di lapangan, Turonggo Budoyo Mugirejo merupakan paguyuban Kuda Lumping asal Blitar Jawa Timur. Kebudayaan Blitar ini diwujudkan dalam bentuk kesenian Kuda Lumping Gagrak Blitaran. Salah satu kesenian Kuda Lumping Gagrak Blitaran yang masih bertahan di Kota Samarinda adalah Paguyuban Turonggo Budoyo Mugirejo. Paguyuban Turonggo Budoyo Mugirejo dalam usahanya melestarikan kesenian ini, melakukan latihan rutin pada setiap hari rabu dan jumat malam. Penulis melihat kegiatan ini merupakan suatu proses belajar kebudayaan.

Koentjaraningrat mengatakan bahwa dalam proses belajar kebudayaan sendiri terdapat tiga konsep, yaitu internalisasi, sosialisasi, dan enkulturasi (Koentjaraningrat, 2009, p. 181). Internalisasi terbentuk dari manusia saat dilahirkan sampai meninggal dunia. Internalisasi merupakan suatu proses pemahaman, pengahayatan, dan penanaman nilai-nilai secara terprogram atau terencana kepada generasi penerus sehingga akan membentuk kepribadian (Martono, 2017, p. 14). Keberlanjutan sebuah kebudayaan khususnya kesenian, perlu adanya generasi penerus dalam mempertahankannya. Internalisasi juga merupakan kegiatan yang mengimplementasikan nilai budaya melalui berbagai metode pembelajaran dan pendidikan mulai indoktrinasi dan brain-washing ${ }^{2}$ (Wardani, 2019, p. 165). Internalisasi budaya dibentuk pada ranah keluarga yang berkembang pada masyarakat. Peran masyarakat sangat berpengaruh pada nilai budaya dari internalisasi yang dilakukuan. Dibutuhkan tokoh masyarakat yang mampu menjadi panutan dan figur yang baik. Pada Paguyuban Turonggo Budoyo Mugirejo, tokoh yang menjadi panutan atau figur adalah ketua dan bopo atau sesepuh. Kesadaran diri dari setiap anggota untuk belajar tari Kuda Lumping Gagrak Blitaran dari aspek musik dan tari dapat terlihat pada saat mereka berlatih hari rabu malam dan jumat malam. Kesadaran diri dari setiap anggotanya untuk berlatih Gagrak Blitaran berjalan linier dengan pemberian pendidikan atau materi yang diberikan oleh pengajar pada paguyuban tersebut.

Menurut Vander dalam Syarif (2017, p. 1), Sosialisasi merupakan proses interaksi sosial yang menyebabkan seorang individu mengenal cara berpikir, berperasaan, dan bertingkah laku sehingga membuatnya dapat berperan serta dalam kehidupan masyarakatnya. Cara

\footnotetext{
2 Brainwashing dalam bahasa Indonesia memiliki arti cuci otak yaitu sebuah upaya rekayasa pembentukan ulang tata berpikir, perilaku dan kepercayaan tertentu menjadi sebuah tata nilai baru, praktik ini biasanya merupakan hasil dari tindakan indoktrinasi.
} 
seseorang berpikir, berperasaan, dan bertingkah-laku itu dipelajari dari anggota masyarakat lainnya. Interaksi seorang individu dengan lingkungannya merupakan proses sosialisasi. Dari proses tersebut individu dibentuk untuk bertingkah laku sesuai dengan tingkah laku kelompoknya, dan belajar menjadi warga masyarakat tempat ia menjadi anggotanya (Berger, 1984, p. 116). Dalam hal ini setiap anggota paguyuban mulai saling berinterkasi dengan lingkungannya. Setiap anggota mulai belajar mengenai cara berpikir, bertingkah laku seperti yang terdapat pada lingkungan sekitarnya. Apa yang disosialisasikan kepada anggota akan mempengaruhi perilaku mereka dalam menjalani kehidupannya. Paguyuban Turonggo Budoyo Mugirejo dalam setiap kegiatan latihannya juga terjadi proses sosialisasi. Sosialisasi yang terjadi pada saat latihan rutin tidak sebatas tentang bagaimana cara menari dan bermain musik, melainkan tentang nilai-nilai serta norma-norma kehidupan juga.

Enkulturasi merupakan proses belajar dan menyesuaikan alam pikiran dan sikap terhadap adat, sistem norma, serta semua peraturan adat yang terdapat dalam kebudayaan seseorang (Hanifah, 2016, p. 62). Proses pembudayaan (enkulturasi) dilakukan oleh orang tua, atau orang yang dianggap senior terhadap anak-anak, atau terhadap orang yang dianggap lebih muda. Tata krama, adat istiadat, keterampilan suatu suku atau keluarga biasanya diturunkan kepada generasi berikutnya melalui proses enkulturasi. Enkulturasi juga merupakan suatu proses yang panjang yaitu sepanjang hidup seseorang. Pada masa awal anak-anak, enkulturasi terjadi tanpa disadari dengan cara dipaksakan. Ketika mereka bertambah dewasa akan belajar secara lebih sadar untuk menerima atau menolak nilai-nilai atau anjuran-anjuran dari masyarakatnya (Suharyanto, 2017, p. 164-165). Proses Enkulturasi juga terjadi di Paguyuban Turonggo Budoyo Mugirejo, banyak sekali ajaran-ajaran dari sesepuh yang diturunkan ke generasi berikutnya. Hal ini dilakukan demi menjaga orisinalitas Gagrak Blitaran yang melekat di paguyuban ini. Seiring berjalannya waktu, ada beberapa kebiasaan yang tidak dilanjutkan ke generasi selanjutnya, namun hal ini tidak mengurangi keaslian Gagrak Blitaran.

Dalam penelitian ini akan mengambil dua sudut pandang dalam skema penelitiannya. Pertama untuk memahami bagaimana karakteristik musik Gagrak Blitaran di Paguyuban Turonggo Budoyo Mugirejo. Kedua untuk memahami proses belajar kebudayaan di Turonggo Budoyo Mugirejo sebagai paguyuban Kuda Lumping Gagrak Blitaran.

\section{Metode}

Tahap awal yang penulis lakukan dalam penelitian ini adalah merancang metode penelitian. Penulis dalam penelitian ini menggunakan metode kualitatif guna memperoleh data-data yang diperlukan. Data yang diperoleh dari lapangan kemudian dijabarkan secara deskriptif analisis. Untuk mendapatkan data yang akurat, penulis menggunakan tiga tahapan, di antaranya menentukan lokasi penelitian, teknik pengumpulan data, dan analisis.

Langkah pertama dalam melakukan perjalanan penelitian lapangan adalah menentukan lokasi penelitian. Lokasi penelitian disesuaikan dengan topik yang penulis teliti, yaitu mengenai kesenian Kuda Lumping. Paguyuban Seni Kuda Lumping Turonggo Budoyo Mugirejo beralamat di Jalan Mugirejo RT 14 Nomor 14, Kelurahan Mugirejo, Kecamatan Sungai Pinang, Kota Samarinda, Kalimantan Timur.

Langkah kedua adalah teknik pengumpulan data yang dilakukan langsung oleh penulis, yaitu dengan menjadi partisipan di lapangan. Adapun teknik pengumpulan datanya mencakup studi kepustakaan, observasi, wawancara, dan dokumentasi penelitian. Studi pustaka yang dilakukan penulis bersumber dari buku-buku kajian musik, kebudayaan, jurnal, artikel, skripsi, 
dan tesis yang dianggap relevan dalam memberikan dasar permasalahan. Observasi yang dilakukan penulis adalah dengan cara melakukan pengamatan langsung lokasi tempat diadakannya pertunjukan dan latihan rutin. Penulis dalam usahanya untuk memperoleh data, melakukan observasi dengan cara ikut serta di setiap kegiatan Paguyuban Turonggo Budoyo Mugirejo. Wawancara yang penulis lakukan melibatkan berbagai narasumber, baik itu informan dari paguyuban maupun masyarakat sekitar. Pada saat kegiatan wawancara, penulis merekam setiap percakapan dalam bentuk audio. Dokumentasi dilakukan penulis pada saat kegiatan latihan rutin dan pementasan Kuda Lumping oleh Paguyuban Turonggo Budoyo Mugirejo. Penulis menggunakan kamera dan handphone sebagai media pengambilan dokumentasi di lapangan.

Langkah terakhir adalah teknik analisis data. Data diperoleh dari kegiatang studi kepustakaan, observasi penelitian, wawancara, dan dokumentasi. Data yang diperoleh dari kerja lapangan kemudian disaring, dianalisa untuk dijadikan tulisan. Data-data yang dianalisis kemudian disusun sehingga hasilnya dapat dikembangkan sebagai bahan dalam pembahasan masalah yang dihadapi. Hasil analisis data yang dianggap relevan dengan pembahasan masalah akan dituliskan secara deskriptif berbentuk narasi dan notasi.

\section{Hasil dan Pembahasan}

\subsection{Pengertian Gagrak Blitaran}

Turonggo Budoyo Mugirejo merupakan salah satu paguyuban Kuda Lumping Gagrak Blitaran di Kota Samarinda. Gagrak Blitaran merupakan acuan dalam proses belajar kebudayaan di Paguyuban Turonggo Budoyo Mugirejo. Hal ini dikarenakan Gagrak Blitaran adalah identitas dari paguyuban ini. Hasil dari proses belajar kebudayaannya juga harus mencerminkan Gagrak Blitaran. Kesenian tari Kuda Lumping sendiri memiliki banyak jenis, khusus di Kota Samarinda terdapat tiga versi atau Gagrak yang sering dipertunjukkan. Ketiga versi tersebut diantaranya Kuda Lumping Tulungagungan, Kediri atau Nganjukan, serta Blitaran. Tari Kuda Lumping Gagrak Tulungagungan, Nganjukan, dan Blitaran pada dasarnya samasama berasal dari Kediri.

Ciri khas pertama pada suatu Gagrak atau pakem kesenian Kuda Lumping adalah gerak tarinya, terutama pada posisi kuda kuda dan perpindahan geraknya. Gagrak Blitaran sendiri memiliki kuda-kuda setengah siku. Perpindahan geraknya sendiri banyak mengangkat kaki, termasuk gerakan melompat. Ciri khas Gagrak Blitaran yang kedua adalah mengenai tarian yang dibawakan pada saat pertunjukan. Paguyuban Turonggo Budoyo Mugirejo selalu membawakan lima tarian dengan Gagrak Blitaran, yaitu Tari Kesatria Tamtama, Celeng, Singo Barong, Jaran Trill, dan Rampokan. Ciri khas ketiga yaitu penggunaan alur cerita yang mewakili kelima tarian yang dibawakan. Kuda Lumping Gagrak Blitaran Paguyuban Turonggo Budoyo Mugirejo mengangkat kisah Panji atau tentang kepahlawanan, yaitu cerita tentang perebutan Dewi Songgo Langit. Ciri khas keempat yaitu mengenai sesaji atau sajen yang diterapkan di Paguyuban Turonggo Budoyo Mugirejo. Ciri khas selanjutnya yang akan penulis bahas adalah mengenai karakteristik musik Gagrak Blitaran di Paguyuban Turonggo Budoyo Mugirejo.

\subsection{Analisis Karakteristik Musik Gagrak Blitaran}

Seni tari kuda Lumping di Paguyuban Turonggo Budoyo dalam gerak tarinya mengikuti 
Gagrak Blitaran. Hal ini berpengaruh juga pada iringan musiknya. Berdasarkan hasil perekaman video serta pengamatan penulis pada saat latihan rutin di Paguyuban Turonggo Budoyo Mugirejo, ada beberapa bentuk irama yang mencirikan Gagrak Blitaran. Bapak Tarjianto selaku pengajar musik gamelan mengatakan ada empat irama yang biasa dipakai oleh Paguyuban Turonggo Budoyo Mugirejo. Keempat irama tersebut diantaranya; sampak, gangsaran, 2-1, dan 1-1. Instrumen musik yang mewakili keempat irama tersebut diantaranya kendang, kenong, kempul, gong suwukan, dan gong ageng. Lima instrumen tersebut merupakan alat musik yang tergolong pembawa irama di tari Kuda Lumping. Berikut ini akan dijelaskan mengenai empat irama yang biasa digunakan untuk mengiringi tarian Kuda Lumping di Paguyuban Turonggo Budoyo Mugirejo.

\subsubsection{Irama Sampak}

Irama pertama yang digunakan untuk mengiringi tarian Kuda Lumping adalah sampak. Sampak merupakan irama yang selalu ada dalam setiap tarian Kuda Lumping baik itu di Turongo Budoyo Mugirejo maupun Paguyuban lain. Kebanyakan orang mengenal sampak dengan istilah irama naikan. Irama sampak biasa dimainkan pada saat adegan pecutan, perangan, tari barongan, dan pengantar proses ndadi para penari. Karakteristik musik irama sampak ialah cepat, keras, suasananya tegang, dan dimainkan secara berulang-ulang.

Sampak apabila dilihat dari sudut pandang karakteristik nada yaitu pitch, duration, intensity, dan timbre, dapat dijelaskan sebagai berikut. Pertama, pitch, sampak merupakan iringan musik yang lebih mengutamakan ritmis daripada melodi. Melodi yang biasa dihadirkan dalam irama sampak biasanya dibawakan oleh instrumen serompet. Kedua, duration atau panjang pendeknya nada yang bisa menunjukkan ritmis atau irama. Sampak memiliki irama atau ritmis yang cepat dan diulang-ulang. Ketiga, intensity atau keras lembutnya nada. Irama sampak memiliki intensitas suara yang keras (forte). Keempat, timbre atau warna nada. Warna suara yang dihasilkan dari sampak bersumber pada instrumen pembawa irama kenong, gong, kempul, kendang. Instrumen-instrumen tersebut dimainkan dengan cara dipukul dengan keras sehingga warna suara yang dihasilkan keras dan tajam. Irama sampak dimainkan dengan tujuan untuk membuat suasana menjadi lebih tegang, membangkitkan emosi baik penari maupun penonton.

\subsubsection{Irama Gangsaran}

Irama kedua yang digunakan oleh Paguyuban Turonggo Budoyo adalah gangsaran. Gangsaran merupakan suatu bentuk gendhing yang mempunyai pola tabuhan 4/4 yang dalam istilah karawitan disebut dengan "irama siji", terdiri atas 8 balungan yang selalu diakhiri dengan gong. Paguyuban Turonggo Budoyo Mugirejo menggunakan irama ini untuk mengiringi tarian celeng. Hal ini dapat dilihat dari langkah kaki penari saat membawakan tarian celeng. Langkah kakinya seirama dengan irama gangsaran, yaitu pada saat bunyi kenong dan gong.

Irama gangsaran apabila dilihat dari sudut pandang karakteristik nada, yaitu pitch, duration, intensity, dan timbre, dapat dijelaskan sebagai berikut. Pertama, pitch, irama gangsaran menggunakan susunan nada yang sederhana dan diulang ulang. Instrumen melodi yang dimainkan adalah demung dan saron. Kedua, duration atau panjang pendeknya nada yang bisa menunjukkan ritmis atau irama. Gangsaran memiliki irama atau ritmis yang 
cenderung lambat tidak seperti sampak, hal ini dikarenakan fungsinya untuk mengiringi tari. Ketiga, intensity atau keras lembutnya nada, irama gangsaran memiliki intensitas suara yang keras namun lebih lembut dari sampak (meso forte). Keempat, timbre atau warna nada. Warna suara yang dihasilkan dari irama gangsaran bersumber dari instrumen kenong, gong, kempul, kendang, saron, dan demung. Instrumen-instrumen tersebut dimainkan sedemikian rupa dengan tujuan untuk mengiringi tarian, yaitu tari celeng. Warna suara yang dihasilkan tidak sekeras irama sampak, hal ini dikarenakan fungsinya yang berbeda, yaitu mengiringi tari celeng.

\subsubsection{Irama 2-1}

Irama 2-1 merupakan irama yang pasti ada dalam setiap pertunjukan kuda lumping, baik itu pada saat mengiringi tarian maupun mengiringi lagu-lagu Jawa. Irama ini dicirikan dengan permainan kempul dan gong. Kempul akan dibunyikan sebanyak dua kali kemudian diakhiri dengan satu kali gong. Irama 2-1 pada dasarnya dibedakan menjadi dua, yaitu pegon dan dangdutan, namun banyak orang yang tidak memahaminya. Hal ini tepat seperti yang dikatakan oleh narasumber:

"Kalau anak-anak sekarang taunya, ya, 2-1, padahal itu ada pegon sama dangdutan. Kebanyakan hampir di semua paguyuban, orang-orangnya itu taunya ya 2-1. Ya, garis besarnya 2-1 tapi dalam penerapannya itu beda, yang dangdutan itu cocoknya buat ngiringin campursarian, lagu-lagu gitu". ${ }^{3}$

Irama 2-1 apabila dilihat dari sudut pandang karakteristik nada yaitu pitch, duration, intensity, dan timbre dapat dijelaskan sebagai berikut. Pertama, pitch, 2-1 merupakan irama dasar tarian Kuda Lumping. Irama ini bisa digunakan sebagai iringan tari maupun iringan lagulagu campursari. Hal ini berpengaruh pada nada-nada yang dimainkan, sebagai pengiring tari susunan nada yang digunakan berupa melodi sederhana dan diulang ulang. Irama 2-1 sebagai pengiring lagu-lagu Jawa atau campursari, tinggi rendahnya nada menyesuaikan melodi lagu tersebut. Kedua, duration atau panjang pendeknya nada yang bisa menunjukkan ritmis atau irama. Irama 2-1 memiliki ritmis yang bervariasi karena fungsinya sebagai pengiring tari dan pengiring lagu. Ketiga, intensity atau keras lembutnya nada, irama gangsaran memiliki intensitas suara yang keras, namun lebih lembut dari sampak (meso forte). Keempat, timbre atau warna nada. Warna suara yang dihasilkan dari irama 2-1 bersumber dari instrumen kenong, gong, kempul, kendang, saron, dan demung. Instrumen-instrumen tersebut dimainkan sedemikian rupa dengan tujuan untuk mengiringi tari dan lagu-lagu campursari. Warna suara yang dihasilkan tidak sekeras irama sampak, hal ini dikarenakan fungsinya yang berbeda. Irama yang dibawakan harus seirama dengan gerak tari serta lagu yang dibawakan. Berikut ini akan dijelaskan mengenai irama pegon dan dangdutan.

\section{a. Irama Pegon}

Irama Pegon merupakan iringan yang pasti digunakan untuk mengiringi tarian Kuda

\footnotetext{
3 Wawancara dengan Tarjianto, Seniman musik gamelan Jawa sekaligus pelatih musik di Paguyuban Turonggo Budoyo Mugirejo, 13 Oktober 2019.
} 
Lumping, baik di Turonggo Budoyo Mugirejo maupun paguyuban lain. Hal ini dikarenakan iringan musik untuk mengiring Kuda Lumping berasal dari irama pegon. Pegon pada dasarnya merupakan suatu gerak tari yang diadaptasi dari gerakan tarian wayang wong. Iringan musik pun harus menyesuaikan pola gerakan tersebut, oleh karena itu iringannya diberi nama irama pegon. Berdasarkan wawancara dengan narasumber, salah satu tarian yang menggunakan irama pegon adalah tari pertama Kesatria Tamtama.

"Kalo pegon itu sendiri sebenarnya gerak tari mas, pethilan dari wayang wong. Jadi gerakannya itu mengikuti gaya dari tari wayang wong. ... kalo irama 2-1 pegon ini biasanya dipakai untuk mengiringi tarian pertama mas, tari Kesatria Tamtama ..."4

\section{b. Irama Dangdutan}

Dangdutan dan pegon digolongkan dalam irama 2-1 karena memiliki kesamaan dalam permainannya. Perbedaan antara irama dangdutan dengan pegon adalah pada fungsinya. Irama dangdutan digunakan untuk mengiringi lagu-lagu campursari serta gendhing Jawa, sedangkan pegon difungsikan untuk iringan gerak tari Kuda Lumping. Irama dangdutan juga selalu ada pada setiap tarian Kuda Lumping di Paguyuban Turonggo Budoyo Mugirejo. Hal ini dikarenakan adanya beberapa lagu-lagu Jawa dan campursari di sela-sela tarian.

\subsubsection{Irama 1-1}

Irama 1-1 merupakan iringan yang biasa digunakan untuk mengiringi tarian Jaran Tril. Irama 1-1 ini apabila didengarkan sepintas hampir sam dengan irama pegon. Perbedaannya terlerak pada pola permainan kempul. Kesamaan ini terjadi dikarenakan gerak tari Jaran Tril juga mengikuti gerakan wayang wong (pegon).

Irama 1-1 apabila dilihat dari sudut pandang karakteristik nada yaitu pitch, duration, intensity, dan timbre dapat dijelaskan sebagai berikut. Pertama, pitch, irama 1-1 merupakan iringan tari yang dimainkan untuk mengiringi tarian jaran tril. Seperti yang telah dijelaskan di atas, bahwa irama 1-1 ini hampir sama dengan 2-1 pegon. Irama 1-1 sebagai pengiring tari, susunan nada yang digunakan berupa melodi sederhana dan diulang ulang. Kedua, duration atau panjang pendeknya nada yang bisa menunjukkan ritmis atau irama. Irama 1-1 memiliki ritmis yang cenderung lambat tidak seperti sampak, hal ini dikarenakan fungsinya untuk mengiringi tari. Ketiga, intensity atau keras lembutnya nada, irama gangsaran memiliki intensitas suara yang keras namun lebih lembut dari sampak (meso forte). Keempat, timbre atau warna nada. Warna suara yang dihasilkan dari irama gangsaran bersumber dari instrumen kenong, gong, kempul, kendang, saron, dan demung. Instrumen-instrumen tersebut dimainkan sedemikian rupa dengan tujuan untuk mengiringi tari. Warna suara yang dihasilkan tidak sekeras irama sampak, hal ini dikarenakan fungsinya yang berbeda. Irama yang dibawakan harus seirama dengan gerak tari yang dibawakan.

\subsection{Proses Belajar Kebudayaan Sendiri}

Penulis melihat kegiatan latihan rutin di Paguyuban Turonggo Budoyo Mugirejo sebagai

\footnotetext{
${ }^{4}$ Wawancara dengan Agung, Seniman Kuda Lumping di Kota Samarinda, 13 Oktober 2019
} 
suatu proses belajar kebudayaan sendiri. Koentjaraningrat menjelaskan proses belajar kebudayaan sendiri ke dalam tiga poin (Koentjaraningrat, 2009, p. 184), yaitu internalisasi, sosialisasi, dan enkulturasi. Berikut ini akan dijelaskan mengenai proses belajar kebudayaan sendiri di Paguyuban Turonggo Budoyo Mugirejo.

\subsubsection{Internalisasi}

Menurut Koentjaraningrat, internalisasi adalah proses dimana individu belajar menanamkan dalam kepribadiannya segala perasaan dan kebutuhan yang diperlukan sepanjang hidupnya. Internalisasi juga merupakan kegiatan yang mengimplementasikan nilai budaya melalui berbagai metode pembelajaran dan pendidikan mulai indoktrinasi (Wardani, 2019, p. 165). Tokoh masyarakat memiliki peran yang penting dalam mempengaruhi proses internalisasi. Pada Paguyuban Turonggo Budoyo Mugirejo, tokoh yang memiliki pengaruh dalam proses internalisasi adalah Bopo. Seorang Bopo secara teknis dalam suatu pertunjukan memiliki tugas sebagai pawang, namun lebih dari itu ada tanggung jawab yang lebih yaitu sebagai 'bapak'. Pengertian bapak di sini adalah sebagai seorang yang membimbing, menasihati, serta menegur apabila anak-anaknya melakukan hal yang tidak baik.

Internalisasi berarti proses menanamkan dan menumbuhkembangkan suatu nilai atau budaya menjadi bagian diri orang yang bersangkutan (Musfah, 2012, p. 47). Para penatua paguyuban terutama bopo berperan menanamkan serta menumbuhkembangkan nilai budaya memberikan doktrin kepada setiap anggota mengenai kesenian Kuda Lumping. Berdasarkan arti dari kata Jaranan itu sendiri, setiap anggota harus belajar dengan sungguh-sungguh. Belajar tentang teknik menari, memainkan musik, maupun tentang nilia-nilai kehidupan seperti saling menghormati dan ketaatan kepada Tuhan Yang maha Kuasa. Di sinilah peran seorang bopo sebagai dalam membimbing anak-anak binaannya.

"Istilah Jaranan itu sendiri berasal dari bahasa Jawa mas, yaitu ajaro seng tenanan (artinya: belajar dengan sunggug-sungguh). Jadi Jaranan itu bukan cuman sekedar pertunjukan terus ada yang kesurupan, dibalik itu sebenarnya punya pesan yang dalam. Kesenian Jaranan itu juga mengajarkan tentang cara saling menghormati dan bertaqwa kepada Tuhan Yang Maha Esa." ${ }^{5}$

Dalam internalisasi budaya pada suatu organisasi, dibutuhkan suatu komunikasi yang baik agar pesan-pesan yang disampaikan dari tingkat teratas dapat diterima dengan baik oleh seluruh anggota organisasi (Tanujaya, 2018, p. 4). Komukikasi yang optimal mempermudah dalam proses internalisasi sehingga setiap anggota memiliki kesadaran tinggi terhadap budaya yang ada di dalam organisasi atau paguyuban. Antara bopo dengan setiap anggota harus memiliki komunikasi yang baik, oleh sebab itu setiap selesai latihan selalu diadakan kegiatan diskusi serta sharing santai. Penulis menemukan jika semakin sering mereka berinteraksi dan berkomunikasi, maka akan semakin mudah pula suatu ajaran terinternalisasi ke dalam diri setiap anggota.

\footnotetext{
${ }^{5}$ Wawancara dengan Agung Nugroho, seniman Kuda Lumping di Kota Samarinda, 13 Oktober 2019
} 


\subsubsection{Sosialisasi}

Sosialisasi adalah suatu konsep dimana kita belajar melalui interaksi dengan orang lain, tentang cara berpikir, merasakan, dan bertindak. Menurut Narwako \& Sytanto (2007, p. 74), lewat proses sosialisasi, individu-individu masyarakat belajar mengetahui dan memahami tingkah laku pekerti apakah yang harus dilakukan, dan tidak. Individu yang sudah sadar untuk belajar kebudayaannya akan masuk ke proses sosialisasi. Individu tersebut mulai berinterkasi dengan orang-orang disekitarnya. Melalui interaksi inilah seseorang berusaha memahami cara berpikir, merasakan, dan bertindak sesuai aturan yang ada.

Banyak anggota paguyuban terutama anak muda tidak memiliki keterampilan dasar dalam kesenian Kuda Lumping.

"Kalo anak-anak ini kebanyakan ya gak punya sklill atau kemampuan yang mumpuni dalam kesenian Kuda Lumping, apalagi soal pakem Gagrak Blitaran. Mereka masih perlu dilatih dan diasah lagi kemampuannya. Ada juga yang gabung sini (paguyuban) itu cuma pengen ikut-ikutan tu ya ada, wes pokoke macem-macem mas." ${ }^{6}$

Anggota paguyuban yang tidak memiliki kemampuan yang cukup akan mulai berinteraksi dengan orang di sekitarnya yang lebih ahli. Interaksi seorang individu dengan lingkungannya merupakan proses sosialisasi. Individu yang tidak memiliki kemampuan tadi akan berinteraksi dengan pelatih di paguyuban, dengan cara mengikuti latihan rutin setiap hari rabu dan jumat malam. Mereka akan mengikuti apa yang diajarkan oleh pelatihnya, sampai mereka benarbenar bisa menerapkannya. Melalui proses sosialisasi yang terjadi pada latihan rutin ini, berdampak pada peningkatan kemampuan atau skill dari anggota paguyuban.

Anggota paguyuban yang rajin mengikuti latihan serta cepat menangkap materi, kemampuannya baik dalam menari maupun memainkan musik akan meningkat. Artinya anggota tersebut berhasil dalam praktek bersosialisasinya, dan hal ini membuatnya dipercaya untuk tampil pada saat pementasan. Sedangkan anggota paguyuban yaang tidak aktif dalam kegiatan latihan rutin, tidak akan dipercaya untuk tampil pada saat pementasan. Hal ini dikarenakan individu tersebut tidak menginternalisasikan ajaran-ajaran yang telah diajarkan oleh bopo dan pelatihnya.

\subsubsection{Enkulturasi}

Proses enkulturasi yang terjadi di Paguyuban Turonggo Budoyo Mugirejo terlihat dari mulai menghilangnya beberapa kebiasaan-kebiasaan lama mereka. Seiring berjalannya waktu Paguyuban Turonggo Budoyo Mugirejo mulai menemukan nilai-nilai yang harus dipertahankan dan tidak. Proses enkulturasi ini berlangsung seumur hidup manusia, seiring bertambahnya pemahaman dan pengalaman, seseorang sadar untuk menerima atau menolak nilai-nilai dari masyarakatnya (Suharyanto, 2017, p. 164). Berdasarkan wawancara dengan naraumber Agung Nugroho selaku bopo di Paguyuban Turonggo Budoyo Mugirejo.

\footnotetext{
${ }^{6}$ Wawancara dengan Agung Nugroho, seniman Kuda Lumping di Kota Samarinda, 13 Oktober 2019
} 
"Kalo dulu mas, ya sampai sekarang juga, kalo pementasan Kuda Lumping itu pasti ada diselingi minum (minuman keras), akhirnya mabuk. Itu dampaknya pasti gak bagus mas, ada dulu pemusiknya teler (mabuk) akhirnya mainnya ngawur (sembarangan). Kadang juga ada penonton yang mabuk minuman gitu ikut masuk nari, ya kelihatannya kayak orang ndadi (kemasukan roh halus), padahal gara-gara mabuk minumkan tadi. Akhirnya malah bikin kerusuhan, wes gak karukauan (tidak jelas) mas. Hal seperti itulah yang akhirnya mencoreng kesenian Kuda Lumping ini. Saya tu gak pengen hal seperti itu jadi kebiasaan, makanya saya tekankan ke anak-anak wes ora usah melu-melu mendem (jangan ikut-ikutan mabuk minuman)."

Berdasakan hasil wawancara tersebut, kebiasaan yang coba dihilangkan dari kesenian Kuda Lumping terutama di Paguyuban Turonggo Budoyo Mugirejo adalah kegiatan minumminuman keras. Pada dasarnya kegiatan minum-minuman keras ini bukanlah termasuk bagian dari kesenian Kuda Lumping. Kegiatan minum ini merupakan suatu kebiasaan yang akhirnya dilakukan terus menerus sampai sekarang, dan memiliki dampak yang kurang baik bagi kesenian Kuda Lumping. Oleh sebab itu bopo serta sesepuh sepakat untuk menghilangkan kebiasaan tersebut dari Paguyuban Turonggo Budoyo Mugirejo.

Hal kedua yang tidak diteruskan lagi di Paguyuban Turonggo Budoyo Mugirejo adalah atraksi-atraksi berbahaya seperti makan beling, bara api, dan ayam hidup. Berdasarkan keterangan narasumber.

"Kalo dulu mas jangan ditanya, kalo cuma atraksi makan beling, bara api, ayam hidup itu pasti ada... tapi semakin ke sini semakin kita jadi tau, sebenernya bukan atraksi-atraksi itu yang paling penting, intinya itu kita melestarikan kesenian warisan dari leluhur kita, kesenian yang adilihung ini. Jangan sampe gara-gara atraksi yang seram ini banyak orang yang memiliki anggapan negatif pada kesenian Kuda Lumping. Intinya saya tekankan ke anak-anak kalau kita ini melestarikan kesenain jadi gak harus pake atraksi-atraksi yang aneh-aneh." $^{8}$

Atraksi-atraksi berbahaya di Paguyuban Turonggo Budoyo Mugirejo saat ini sudah tidak lakukan lagi. Hal ini dikarenakan tujuan utama paguyuban ini dibentuk ialah untuk melestarikan kesenian. Oleh karena itu bopo Agung menekankan kepada setiap anggota untuk berfokus pada pelestarian seni bukan pada atraksi-atraksinya. Secara universal tidak ada kebudayaan yang tidak berubah, tidak ada kebudayaan yang tidak adaptif terhadap bentuk perubahan. Hal ini yang menyebabkan kebudayaan bersifat dinamis dan adaptif (Yudnya \& Ardika, 2017, p. 1). Paguyuban Turonggo Budoyo Mugirejo sebagai warisan kebudayaan Jawa juga mengalami perubahan seiring berjalannya waktu. Hal ini terjadi karena adanya proses enkulturasi. Bertambahnya pemahaman serta pengalaman membuat para seniman Kuda Lumping di Paguyuban Turonggo Budoyo Mugirejo menyesuaikan diri dengan kebutuhan saat ini. Perubahan yang terjadi di Paguyuban Turonggo Budoyo Mugirejo tidak menghilangkan identitas mereka sebagai kesenian Kuda Lumping Gagrak Blitaran. Hal-hal utama seperti bentuk tari, iringan musik, kelengkapan sesaji masih dipertahankan sesuai apa yang diwariskan leluhur mereka.

\footnotetext{
7 Wawancara dengan Agung Nugroho, seniman Kuda Lumping di Kota Samarinda, 13 Oktober 2019

${ }^{8}$ Wawancara dengan Agung Nugroho, seniman Kuda Lumping di Kota Samarinda, 13 Oktober 2019
} 


\section{Simpulan}

Turonggo Budoyo Mugirejo merupakan paguyuban seni tari kuda lumping Gagrak Blitaran yang ada di Kota Samarinda. Paguyuban Turonggo Budoyo Mugirejo dalam penampilannya selalu membawakan lima tarian. Tarian tersebut diantaranya Tari Kesatria Tamtama (pembuka), Celeng, Singo Barong, Jaran Tril, dan Rampokan. Kelima tarian tersebut mengikuti alur cerita perebutan Dewi Songgo Langit. Kelima tarian serta alur cerita yang diikuti menggambarkan Kuda Lumping Gagrak Blitaran. Paguyuban Turonggo Budoyo Mugirejo, dalam setiap penampilannya tidak pernah terlepas dengan unsur pendukung seperti sesaji yang masih baku, seperti yang diajarkan pendahulunya. Iringan musik juga menjadi hal yang penting dalam kesenian Kuda Lumping Gagrak Blitaran.

Turonggo Budoyo Mugirejo sebagaia paguyuban tari Kuda Lumping Gagrak Blitaran memiliki karakteristik iringan musik. Penulis memperoleh hasil dari penelitiannya, bahwa karakteristik musik Pakem Gagrak Blitaran ini ditunjukkan pada empat irama. Irama tersebut adalah sampak, gangsaran, 2-1 (pegon dan dangdutan), serta satu-satu. Irama ini dimainkan oleh instrumen yang bersifat sebagai pembawa irama, yaitu: kendang, kenong, kempul, gong suwukan, dan gong ageng. Instrumen kendang memiliki tiga motif dalam stiap irama yaitu untuk memulai, merubah tempo, serta menutup iringan. Instrumen kenong, kempul, gong suwukan, dan gong ageng hanya memiliki satu motif pada setiap irama. Motif tersebut dimainkan berulang ulang mengikuti tenda dari instrumen kendang.

Proses belajar kebudayaan di Paguyuban Turonggo Budoyo Mugirejo terjadi pada saat latihan rutin setiaphari rabu dan jumat malam. Proses belajar kebudayaan pada kegiatan latihan rutin ini meliputi internalisai, sosialisasi, dan enkulturasi. Melalui proses belajar kebudayaan ini setiap anggota diajarkan keterampilan dasar baik dalam menari maupun memainkan iringan musik Kuda Lumping. Lebih dari itu setiap anggota juga ditanamkan sifat untuk bertanggung jawab, rajin, serta menjalin kerjasama, yang nantinya berguna dalam kehidupan bermasyarakat. Bopo, pelatih, ketua paguyuban, serta para sesepuh adalah tokoh/ figur yang bertanggung jawab membimbing setiap anggota.

\section{Referensi}

Suharyanto, A. (2015). Pendidikan dan Proses Pembudayaan dalam Keluarga. JUPIIS: Jurnal Pendidikan Ilmu-Ilmu Sosial, 7(2), 162-165. https://doi.org/10.24114/jupiis.v7i2.3123

Anwar. (2018). Paradigma Sosialisasi dan Kontribusinya terhadap Pengembangan Jiwa $\begin{array}{llll}\text { Beragama } \quad \text { Anak. } & \text { Al-Maiyyah, }\end{array}$ https://doi.org/10.35905/almaiyyah.v11i1.544

Dewi, H. (2016). Keberlanjutan dan Perubahan Seni Pertunjukan Kuda Kepang di Sei Bamban, Serdang Bedagai, Sumatera Utara. Panggung: Jurnal Seni Budaya, 26(2), 140-150. http://dx.doi.org/10.26742/panggung.v26i2.172

Dewi, R. S. (2012). Keanekaragaman Seni Tari Nusantara. Jakarta: Balai Pustaka.

Hanifah, N. (2016). Sosiologi Pendidikan. Sumedang: UPI Sumedang Perss.

Herusatoto, B. (2008). Simbolisme Jawa. Yogyakarta: Penerbit Ombak.

Yadnya, I. B. P., \& Ardika, I W.. (2017). Dinamika Manusia dan Kebudayaan Indonesia dari Masa ke Masa. Bali: Pustaka Larasan. 
Indranata, I. (2008). Pendekatan Kualitatif untuk Pengendalian Kualitas. Jakarta: Universitas Indonesia.

Kementerian Desa, Pembangunan Daerah Tertinggal dan Transmigrasi RI. (2015). Transmigrasi Masa Doeloe, Kini dan Harapan Kedepa. Jakarta: Direktorat Bina Potensi Kawasan Transmigrasi.

Koentjaraningrat. (2009). Pengantar IImu Antropologi. Jakarta: Rineka Cipta.

Martono. (2017). Internalisasi Nilai-nilai Tradisional di Tengah-tengah Smart City. Prosiding Seminar Nasional FMIPA-UT 2017, 12 Oktober 2017, 11-22.

Merriam, A. P. (1964). The Antropolog of Music. United States: Noorthwestern University Press.

Moleong, L. J. (2008). Metodologi Penelitian Kualitatif. Bandung: PT. Reamaja Rosdakarya.

Musfah, J. (2012). Pendidikan Holistik: Pendekatan Lintas Perspektif. Jakarta: Kencana.

Narwako, D., \& Suyanto, B. (2007). Sosiologi Teks: Pengantar dan Terapan, Jakarta: Prenada Media Group.

Nettl, B. (2012). Teori dan Metode Dalam Etnomusikologi, Jayapura: Jayapura Center of Music.

Noor, J. (2017). Metodologi Penelitian Skripsi, Tesis, Disertasi, dan Karya Ilmiah. Jakarta: Kencana.

Prier SJ, K. (1996). Ilmu Bentuk Musik. Yogyakarta: Pusat Musik Liturgi.

Prastowo, A. (2016). Metode Penelitian Kualitatif dalam Prespektif Rancangan Penelitian. Yogyakarta: Ar-Ruzz Media.

Radhia, H. A. (2016). Dinamika Seni Pertunjukan Jaran Kepang di Kota Malang. Jurnal Kajian Seni, 2(2), 164-177. https://doi.org/10.22146/jksks.12140

Semiawan, C. R. (2010). Metode Penelitian Kualitatif Jenis, Karakteristik dan Keunggulannya. Jakarta: Grassindo.

Soedarsono, R. M. (2001). Metodologi Penelitian Seni Pertunjukan dan Seni Rupa. Bandung: Masyarakat Seni Pertunjukan Indonesia.

Supanggah, R. (1995). Etnomusikologi. Yogyakarta: Yayasan Bentang Budaya.

Tanujaya, B. C., Tjahjo, J. D. W., \& Indrayani, I. I. (2018). Internalisasi Budaya Organisasi Melalui Komunikasi dalam Organisasi Musik Cognatio Orkest. Jurnal E-Komunikasi, 6(2). http://publication.petra.ac.id/index.php/ilmu-komunikasi/article/view/8272

Utoyo, B. (2017). Geografi: Membuka Cakrawala Dunia. Bandung: PT Setia Purna Inves.

Vivian, Y. I. (2018). Teori Musik Barat I. Samarinda: Mulawarman University Press.

Wardani. (2019). Internalisasi Nilai dan Konsep Sosialisasi Budaya Dalam menjunjung Sikap Pemersatu Masyarakat. Nusantara: Jurnal Ilmu Pengetahuan Sosial, 6(2), 164-174. http://dx.doi.org/10.31604/jips.v6i2.2019.164-174

Yudoyono, B. (1984). Gamelan Jawa Awal-Mula, Makna Masa Depannya. Jakarta: PT. Karya Unipress. 